\title{
İlkokul ve Ortaokul Yöneticilerinin Yönetsel Etkililik Düzeyi
}

\author{
Yrd. Doç. Dr. Süleyman GÖKSOY \\ Düzce Üniversitesi \\ Eğitim Fakültesi \\ goksoys@hotmail.com
}

\author{
Yrd. Doç. Dr. Mahmut SAĞIR \\ K. Sütçü İmam Üniversitesi \\ Eğitim Fakültesi \\ msagir@ksu.edu.tr
}

\author{
Şenyurt YENIPINAR \\ Milli Eğitim Bakanlığı \\ yenipina@gmail.com
}

Özet: Okul yöneticilerinin yönetsel etkililik düzeylerinin okulların örgütsel etkiliklerinin temel belirleyicilerinden biri olduğu düşünülmektedir. Bu nedenle araştırmada; öğretmen görüşlerine göre ilk ve ortaokul yöneticilerinin etkililiğinin belirlemesi hedeflenmiştir. Bu araştırma mevcut durumu tespit etmeyi amaçladığı için betimsel yöntemlerden tarama modelidir. Araştırmanın örneklemini, Konya ili merkez ilçede görevli oldukları okulda en az bir öğretim yılı görev yapmış öğretmenler arasından "Basit Tesadüfi Örnekleme" yoluyla belirlenen 112 öğretmen oluşturmaktadır. Araştırmada verileri toplamak amacıyla, Tanrıöğen'in (1988) Türkçe'ye çevirdiği Washington Yönetici Değerlendirme Envanteri kullanılmışır. Araştırmada öğretmenler ilk ve ortaokul yöneticilerini 17 madde bulunan "Teknik Beceriler", 19 madde bulunan "Insan ilişkileri Becerileri" ve 21 madde bulunan "Kavramsal Beceriler" boyutlarının her üçünde de "her zaman" düzeyinde etkili buldukları yönünde görüş belirtmişlerdir.

Anahtar Kelimeler: Yönetsel etkililik, ilk ve ortaokul, okul yöneticileri.

\section{Managerial Effectiveness Levels of Primary School and Secondary School Administrator}

\begin{abstract}
The aim of this research is; after learning teachers' perceptions about primary and elementary school administrators' effectiveness, determining, making comments and suggestions about it. To achieve these goals, the following questions will be answered. This research is a descriptive study to determine the current situation. Survey method was used and research was carried out by the data based on surveys. Teachers, who are working in Konya Primary School's management in 2012/2013 academic year, created the working part of the research. Working part of this descriptive research was created by 112 teachers who are working in Konya Primary and elemantary school and they participated as volunteers. Teachers who had worked in their school at least for one year were chosen for this working part The following results are obtained at the end of the research including teachers' opinions about the elementary school administrators' levels of managerial effectiveness: Primary and elementary school administrators are always effective in the cases of technical skills, human relations skills and conceptual skill. So we can say that primary and elementary school administrators are effective.
\end{abstract}

Key Words: Managerial effectiveness, primary school, elementary school, school administrators. 


\section{GíRiş}

Örgütsel etkililiğini belirleyen pek çok değişkenin varlığından söz edilebilir. Ancak örgüt yöneticilerinin etkililiği örgütün etkililiğinde en önemli değişkenlerden biri olduğu düşünülmektedir. Çünkü örgüt yöneticileri örgütün madde ve insan kaynağını örgütün amaçları doğrultusunda eşgüdümleşmede birinci derecede sorumlu olan kişilerdir. Eğitim hizmeti üreten okulların etkililiğini sağlama görevi de temelde okul örgütünün yöneticisinde olduğu düşünülmektedir.

Okul yönetimi, okuldaki madde ve insan kaynaklarının amaç gerçekleştirecek biçimde harekete geçirilmesi ve eşgüdümleşmesi sürecidir (Bayrak, 2001, 207).Okulların amacı, özgür ve çok yönlü düşünebilen, sosyal yönü güçlü, ruhen ve bedenen sağlıklı, girişimci, vizyon sahibi ve sosyal kültürü özümsemiş bireyler yetiştirmektir (Can, 2004, 128). Okul yöneticilerinin temel amaçları da kurumlarının etkili olmalarını sağlamaktır. Bu nedenle öteden beri sürüp giden verimliliği ve etkililiği artırma çabaları zamanımızda daha da yoğunluk kazanmıştır. Bu istek etkililik ve ilgili kavramların tanımlanması ve ölçülmesi gereğini de beraberinde getirmiştir (Can,1994,263). Eğitim sistemi içerisinde okullar ve bunların yöneticileri kendilerinden eğitim talep eden bireylere yüksek nitelikte eğitim sunmak zorundadırlar (Açıkalın ve Çınkır, 2006, $132)$.

Yönetici karı ya da riski başkalarına ait olmak üzere hizmet veya mal üretmek için üretim öğelerinin alımını yapan veya yaptıran, bunları belirli ihtiyaçları doyurmak amacına yönelten, işletmeyi girişimci adına çalıştırma sorumluluğu olan kimsedir (Tengilimoğlu ve diğerleri, 2008, 79). Kısaca yönetici bir örgütün amacını gerçekleştirebilmesi için başkaları vasıtasıyla iş gören, örgüt yapısını kullanarak başkalarını sevk ve idare eden kişidir (Ilgar, 2005; Koçel, 2003).

Okul yöneticileri okulun daha nitelikli bir eğitim hizmeti üretmesi konusunda, üst yönetim kademelerine, öğretmenlere, öğrencilere, velilere ve topluma karşı birinci derecede sorumluluğu olan kişidir (Dönmez, 2004, 55) Okul yöneticiliği yeri sıradan birileri tarafından doldurulamayacak bir görevdir. Bürokratik dilde bu görevlere "kritik görevler" denir ve bu makamda oturanlar "kritik personel" olarak önem görür (Açıkalın, 2006, 155). Bu nedenle eğitim örgütlerinin etkililiğinde en temel rol örgüt yöneticilerinindir. Bu nedenle okul yöneticilerinin okul örgütünün etkililiğinin sağlanmasında en kritik role sahip oldukları söylenebilir.

Her örgüt bir takım amaçları gerçekleştirmek amacıyla kurulmaktadır. Bu nedenle amaçlarını gerçekleştiren ve bu yolla çevrenin beklentilerine cevap veren örgütler varlıklarını 
sürdürebilecektir. Ancak örgüt amaçlarını gerçekleştiremez ise varlık nedenini kaybedecek ve bir süre sonra dağılma sürecine girecektir. Dolayısıyla örgütsel etkililik düzeyi her örgüt varlığı için hayati önem taşımaktadır.

Örgütsel etkililik, örgütsel amaçları ve işlevleri gerçekleştirme düzeyi, örgütsel, yönetsel süreçlerin beklentileri karşılama düzeyi, örgütün çevreden kaynak sağlama yeteneği, örgütsel çıktılar yönünden sağlanan başarı düzeyi, örgütün çevreye uyum sağlama durumu, çevresel beklentileri karşılama yeteneği biçiminde tanımlanmaktadır (Balcı, 2001; Karslı, 1998; Şişman ve Turan, 2005). Örgütsel davranış çerçevesinde ise etkililik; verimlilik, kalite, etkenlik, esneklik, doyum, rekabet edebilirlik ve gelişme arasındaki optimal ilişki olarak tanımlanmıştır. (Gibson,1994, aktaran Karslı, 1998,74). Dolayısıyla örgütsel etkililik, açık ve kesin olarak belirlenen örgütsel amaçların başarılmasıyla ilgilidir (Argon ve Eren, 2004,12). Tüm bu nedenlerle amaçlarını gerçekleştirme oranı yükseldikçe örgütsel etkilikte yükselmektedir.

Bir örgütte etkililik sona erdiğinde, örgütün amacı istenilen ölçüde gerçekleştirilmediğinde, bireylerde ortak amaca katkıda bulunma isteği kaybolur. Bu durum örgütün varlığı için zorunlu öğelerden birinin yok olması anlamına gelir ki örgütün varlığı tehlikeye girer. Eğer gösterilen çabanın sonunda elde edilen doyum, katlanılan özveriyi aşarsa, bireylerde ortak amaca katkıda bulunmaya isteklilik görülür ve örgütsel etkililik gerçekleşir (Aydın,1991,14). Örgüt içinde amaçların gerçekleşmesinden sorumlu olanlar, örgütteki öğeleri amaçlar doğrultusunda işe koşan yöneticilerdir.

Birer eğitim örgütleri olan okulların yöneticilerinin etkililik düzeyi örgütün amaçlarının gerçekleşme derecesini olumlu ya da olumsuz yönde etkilemesi beklenmektedir. Bir başka deyişle okul yöneticilerinin yönetsel etkililik düzeyi örgütsel etkililik düzeyinin en temel belirleyicisi olmaktadır.

Yöneticinin görevi örgütsel, grup ve bireysel düzeydeki etkililik nedenlerini tanımlayabilmektir. Her üç düzeydeki etkililik nedenleri şekil 1'de belirtilmektedir (Can,1994,263).

\begin{tabular}{|l|l|l|}
\hline Bireysel Etkililik & Grup Etkililiği & Örgütsel Etkililik \\
\hline Nedenler: & Nedenler: & Nedenler: \\
\hline Yetenek & Birlik & Çevre \\
Beceri & Önderlik & Teknoloji \\
Bilgi & Yapı & Stratejik tercihler \\
Tutum & Saygınlık & Yapı \\
Güdüleme & Roller & Süreçler \\
Stres & Normlar & Kültür \\
\hline
\end{tabular}

Şekil 1: Etkililik Düzeyleri ve Ölçütleri (Can, 1994,263). 
Bütün örgütler gibi okullar da "etkili" ve "verimli" oldukları sürece varlıklarını koruyabilirler (Aydın, 1994, 15). Okulların etkili olarak yönetilmesi, sahip oldukları insan ve madde kaynaklarının kullanılarak amaçlarııı gerçekleştirilmesi, bu kaynakları amaçlar doğrultusunda işe koşan okul yöneticilerinin etkili olmaları ile sağlanabilir. Etkili okulların mı etkili yöneticiler yetiştirdiği, yoksa etkili yöneticilerin mi etkili okullar geliştirdiği tartışılmıştır. Okul etkililiğine ilişkin yapılan araştırmalar, yöneticilerin okul etkililiğinde kritik bir rol oynadığını ileri sürmektedir. Okullar öğrencilerin öğrenmelerinde bir fark yaratırken, yöneticiler de okullar arasında bir fark yaratmaktadır (Tanrı̈ğen, 1988,5).

Yapılan araştırmalarda (Balcı, 1988) okulların etkililiği sürecinde en önemli değişken o okulun yöneticisidir. Ekili okul ancak, okul yöneticisinin etkililik ilkelerinin benimsemesi ve uygulaması ile mümkün olabilmektedir (Korkmaz, 1997, 55). Yönetici, konumu ya da bilgileri nedeniyle, görevi gereği bütüne ilişkin performans ve sonuçlar üzerine önemli etkisi olan kararları vermesi beklenen kişidir (Drucker, 1992, 22). Okul yöneticileri, öğrencilerin güdülenmesini sağlayacak olumlu bir okul ortamı ve bu ortamı sağlayacak bir kültür oluşturarak akademik başarının da artmasını sağlayabilir. Şöyle ki etkili okul konusunda yapılan çalışmalar, okulun eğitim kadrosunu sürekli olarak eğitilmesini ve geliştirilmesi etkili okulun özelliklerinden biri olarak belirlenmiştir(Şişman, 1996, 28).

Okulda eğitim-öğretim sürecinin hedeflerine ulaşmasından sorumlu olan okul yöneticilerinin, bu sorumluluklarını etkili bir biçimde yerine getirebilmeleri birtakım özelliklere ve becerilere sahip olmaları ile olanaklı görülmektedir. Etkili yöneticilere ilişkin olarak yapılan çalışmalardan, etkili bir yöneticinin bir yandan okulun işletmeye ilişkin ihtiyaçlarını karşılarken, bir yandan da akademik gereksinmelerini karşıladıkları anlaşımaktadır (Tanrıöğen, 1988, 249). Eğitim, insanın doğumundan başlayıp ölümüne kadar devam eden bir süreçtir. Bu sürecin formal olarak ilk basamağını ilk ve ortaokullar oluşturmaktadır. Illk ve ortaokulların örgütsel amacını en etkili şekilde gerçekleştirmesi bu açıdan büyük önem taşımaktadır.

Örgütün amacına ulaşabilmesi için sahip olduğu ve yararlanabileceği kaynakları en iyi şekilde kullanması mümkün olabilir. Örgütün amaçlarına ulaşma derecesi bir bakıma kaynakları etkili kullanabilmeyi zorunlu kılmaktadır. Bu nedenle örgütün kaynaklarının kullanılma durumlarının belirlenmesi zorunludur. Okul yöneticilerinin etkililik düzeylerinin okulların örgütsel etkiliklerinin temel belirleyicilerinden biri olduğu düşünülmektedir. Çünkü örgüt içinde amaçların gerçekleştirilmesinden sorumlu olanlar, örgütteki öğeleri amaçlar doğrultusunda işe koşan yöneticilerdir. Bu yönü ile okulların etkililiği üzerinde en önemli etkiye sahip olan kişiler 
okul yöneticileridir. Yöneticinin etkililik düzeylerinin bilimsel araştırmalarla sınanması, eğitim örgütlerinin amaçlarına ulaşmasına katkı sağlayacaktır.

\section{Araştırmanın Amacı}

Araştırmanın amacı öğretmen görüşlerine göre ilk ve ortaokul yöneticilerinin yönetsel etkililik düzeylerini belirlemektir. Araştırmanın ilk ve ortaokulların yöneticilerinin yönetsel etkililik düzeylerinin arttırılmasında ve eğitim örgütlerinin amaçlarını daha etkili bir şekilde gerçekleştirilmesinde yol göstereceği düşünülmektedir.

Bu amaçla çalışmada aşă̆ıdaki alt problemlere cevap aranmıştır.

1. İlk ve ortaokul yöneticilerinin etkililik düzeyleri ile ilgili öğretmen görüşleri nedir?

2. İlk ve ortaokul yöneticilerinin etkililik düzeyleri ile ilgili öğretmenlerin cinsiyet değişkeni bakımından görüşleri arasında anlamlı fark var mıdır?

3. İlk ve ortaokul yöneticilerinin etkililik düzeyleri ile ilgili öğretmenlerin yaş değişkeni bakımından görüşleri arasında anlamlı fark var mıdır?

4. İlk ve ortaokul yöneticilerinin etkililik düzeyleri ile ilgili öğretmenlerin hizmet yılı değişkeni bakımından görüşleri arasında anlamlı fark var mıdır?

\section{Yöntem}

\subsection{Araştırmanın Yöntemi}

Araştırmanın yöntemi, mevcut durumu tespit etmeyi amaçladığı için betimsel araştırma yöntemlerinden tarama modelidir. Tarama modelleri, geçmişte ya da halen var olan bir durumu var olduğu şekliyle betimlemeyi amaçlayan araştırma yaklaşımlarıdır. Araştırmaya konu olan şey, birey ya da nesne, kendi koşulları içinde ve olduğu gibi tanımlanmaya çalışılır. Onları, herhangi bir şekilde değiştirme, etkileme çabası gösterilmez (Karasar, 2011, 77).

\subsection{Araştırmanın Evren ve Örneklemi}

Araştırmanın evreni Konya ili merkez ilçede görev yapan ilk ve ortaokul öğretmenleridir. Araştırmanın örneklemi ise evrenden "Basit Tesadüfi Örnekleme" yöntemi ile belirlenen 112 öğretmen oluşturmaktadır. Araştırmanın örneklemi belirlenirken görev yaptıkları okulda en az bir öğretim yılı çalışmış olmalarına bakılmıştır. Araştırmanın örnekleminde yer alan öğretmenlerin kişisel bilgilerine ilişkin veriler Tablo 1'de gösterilmiştir.

Bartın Üniversitesi Eğitim Fakültesi Dergisi Cilt 2, Sayı 1, s. 18 - 31, Yaz 2013, BARTIN-TÜRKIYE Bartin University Journal of Faculty of Education, Volume 2, Issue 1, p. 18 - 31, Summer 2013, BARTIN-TURKEY 
Tablo 1: Öğretmenlere Ait Kişisel Bilgiler

\begin{tabular}{|c|c|c|c|}
\hline Değişken & & $f$ & $\%$ \\
\hline \multirow[t]{4}{*}{ Cinsiyet } & Kadın & 52 & 46,4 \\
\hline & Erkek & 60 & 53,6 \\
\hline & $21-30$ & 44 & 39,3 \\
\hline & $31-40$ & 48 & 42,9 \\
\hline \multirow[t]{3}{*}{ Yaş } & $41-50$ & 18 & 16,1 \\
\hline & 51 ve üst. & 2 & 1,8 \\
\hline & 1-5 yıl & 30 & 26,8 \\
\hline \multirow{4}{*}{ Hizmet Yılı } & 6-10 yıl & 42 & 37,5 \\
\hline & 11-15 yıl & 24 & 21,4 \\
\hline & $16-20$ yıl & 10 & 8,9 \\
\hline & 21 ve üstü & 6 & 5,4 \\
\hline
\end{tabular}

Araştırmaya katılan sınıf öğretmenlerinin 52'si kadın, 60'ı erkektir. 44'ü 21-30, 48'i 3140, 18'i 41-51 ve 2'si 51 ve üstü yaş aralığındadır. Araştırmaya katılan öğretmenlerinin 30'u 1-5 yıl, 42'si 6-10 yıl, 24'ü 11-15 yıl, 10'u 16-20 yıl ve 6'sı 21 ve üstü kıdem yılına sahiptir. Ayrıca öğretmenlerinin 1'i 2-3 yıllık yüksekokul, 100'ü 4 yıllık lisans, 8'i yüksek lisans ve 4'ü ise doktora düzeyinde eğitime sahiptirler.

\subsection{Verilerin toplanması:}

Araştırmada verileri toplamak amacıyla, Tanrı̈ğen'in $(1988,145)$ Türkçe'ye çevirdiği Washington Yönetici Değerlendirme Envanteri kullanılmıştır. Teknik beceriler, insan ilişkileri becerileri ve kavramsal beceriler şeklinde 3 alt boyuttan oluşan ölçeğin güvenirlik çalışması Tanrıöğen (1988) tarafından yapılmış, teknik beceriler boyutunda güvenirlik katsayısı .91, insan ilişkileri becerileri boyutunda .85 , ve kavramsal beceriler boyutunda ise .91 olarak, güvenilirlik katsayısı ölçeğin tamamı için ise .92 , olarak hesaplanmıştır. Mevcut araştırmada ise ölçeğin cronbach alpha katsayısı toplam ölçekte .94 , teknik beceriler alt boyutunda .95 , insan ilişkileri becerileri alt boyutunda .95 ve kavramsal beceriler alt boyutunda ise .90 olarak tespit edilmiştir. Bu duruma göre Washington Yönetici Değerlendirme Envanterinin Türkçeye uyarlanmış halinin güvenilir olduğu söylenebilir.

\subsection{Araştırmanın Veri Çözümleme Teknikleri}

Öğretmenlerin kişisel değişkenlerine ait verilerin analizinde aritmetik ortalama ve standart sapma değerleri kullanılmıştır. "Aritmetik ortalamaların değerlendirilmesinde; “Aralık Genişliği=Dizi Genişliği (Ranj)/Grup Sayısı" formülünden faydalanarak, 4/5=0,80 olarak puan aralıkları belirlenmiştir" (Tekin, 1996). Araştırmada uygulanacak kestirisel analiz yöntemlerine 
karar vermek için verilerin normal dağılımına ve homojenliğine bakılmıştır. Normal dağılım için Kolmogorov Smirnov analizi yapılmış ve $p>0,05$; homojenlik için ise homojenlik analizi yapıımış ve yine $p>0,05$ olarak belirlenmiştir. Örneklem sayısının da yeterli büyüklükte olması nedeniyle verilere parametrik analiz yöntemlerinin uygulanmasına karar verilmiştir. Buna göre, cinsiyet, öğretmen görüşleri arasında anlamlı bir farklıık bulunup bulunmadığını belirlemek için bağımsız örneklem t testi; hizmet yılı ve yaş değişkeni için ise tek yönlü (one way) ANOVA analizi teknikleri uygulanmıştır. Gruplar arasında anlamlı farklılığı ortaya çıkarmak için ise Tukey analizi uygulanmıştır. Anlamlılık düzeyi $p=0,05$ olarak alınmıştır.

Tablo 2: Beşli Dereceleme Ölçeğinin Puan Sınırları

\begin{tabular}{|c|c|c|}
\hline Derece & Seçenek Puanları & Seçeneklere Ait Puan Sınırları \\
\hline Hiç & 1 & $1.00-1.79$ \\
\hline Çok Seyrek & 2 & $1.80-2.59$ \\
\hline Ara Sıra & 3 & $2.60-3.39$ \\
\hline Çoğu Zaman & 4 & 3.40-4.19 \\
\hline Her Zaman & 5 & $4.20-4.99$ \\
\hline
\end{tabular}

\section{BULGULAR}

Araştırmada ilk ve ortaokul yöneticilerinin yönetsel etkililikte "teknik beceriler" boyutuna ilişkin öğretmen görüşleri Tablo 3’te verilmiştir.

Tablo 3: Okul Yöneticilerinin “Teknik Becerilerine” iliş̧kin Öğretmen Görüşleri

\begin{tabular}{|c|c|c|c|c|}
\hline & Madde & Ifade & $\mathbf{X}$ & SS \\
\hline \multirow{10}{*}{ 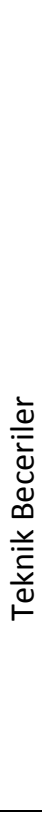 } & 6 & $\begin{array}{l}\text { Öğrenci velilerinin, okul personelinin ve öğrencilerin okuldaki faaliyetler } \\
\text { hakkında görüşlerini bildirebilmeleri için imkânlar sağlar. }\end{array}$ & 4,47 & 0,82 \\
\hline & 8 & $\begin{array}{l}\text { Okul personeline, okul çevresindeki sosyal ve kültürel faaliyetlere katılmaları } \\
\text { için kolaylık gösterir. }\end{array}$ & 4,40 & 0,88 \\
\hline & 12 & $\begin{array}{l}\text { Okuldaki faaliyetlerin öğretmenler tarafından desteklenmesini ister ve bunu } \\
\text { gerçekleştirebilmek için de çeşitli yollar geliştirir. }\end{array}$ & 4,59 & 0,70 \\
\hline & 14 & $\begin{array}{l}\text { Okulda yapılan tüm işlerde yetki ve sorumluluğun kime ait olduğunun } \\
\text { bilinmesine özen gösterir. }\end{array}$ & 4,45 & 0,82 \\
\hline & 19 & Okul içerisinde etkili bir haberleşme ağı oluşturur. & 4,50 & 0,80 \\
\hline & 20 & $\begin{array}{l}\text { Okuldaki öğretmenlerin, zamanlarını iyi bir biçimde değerlendirebileceği bir } \\
\text { okul çevresi hazırlar ve düzenler. }\end{array}$ & 4,30 & ,805 \\
\hline & 22 & $\begin{array}{l}\text { Okuldaki personelin kendi resmi görevlerine ilişkin bilgi edinmesine yardım } \\
\text { eder. }\end{array}$ & 4,56 & 0,69 \\
\hline & 25 & Okul yönetiminin günlük görevlerini başarılı olarak yerine getirir. & 4,60 & 0,67 \\
\hline & 29 & $\begin{array}{l}\text { Okuldaki personel, araç-gereç ve çeşitli kaynaklar hakkında etkili bir kayıt } \\
\text { tutma sistemi geliştirir. }\end{array}$ & 4,37 & 0,65 \\
\hline & 31 & $\begin{array}{l}\text { Çeşitli faaliyetler düzenleyerek öğretmen-veli etkileşimini güçlendirmeye } \\
\text { çalışır. }\end{array}$ & 4,40 & 0,83 \\
\hline
\end{tabular}




\begin{tabular}{|c|c|c|c|}
\hline 37 & Okul hakkında çevreye bilgi vermek için çeşitli programlar hazırlar. & 3,98 & 0,98 \\
\hline 41 & $\begin{array}{l}\text { Okul personelinin ihtiyaçlarını ve görevlerini belirlemek için pratik yollar } \\
\text { geliştirir. }\end{array}$ & 4,47 & 0,96 \\
\hline 42 & $\begin{array}{l}\text { Hizmet-içi eğitim programlarına katılmaları için okuldaki öğretmenleri teşvik } \\
\text { eder. }\end{array}$ & 4,27 & 0,86 \\
\hline 46 & $\begin{array}{l}\text { Okul çevresinin bilgi kaynaklarından personelimin yararlanabilmesi için yollar } \\
\text { bulur. }\end{array}$ & 4,33 & .831 \\
\hline 52 & $\begin{array}{l}\text { Personel, malzeme ve kaynak ihtiyaçlarını tespit etmek için etkili yollar } \\
\text { geliştirir. }\end{array}$ & 4,42 & 0,82 \\
\hline 58 & Okuldaki araç-gereç ve donanımın etkili bir şekilde kullanılmasını sağlar. & 4,54 & 0,73 \\
\hline 59 & Okul ile okul çevresi arasında etkili bir haberleşme ağı oluşturur. & 4,51 & 0,81 \\
\hline
\end{tabular}

Tablo 3 incelendiğinde öğretmenler okul yöneticilerinin $X=4,60$ aritmetik ortalama ile “okul yönetiminin günlük görevlerini başarılı olarak yerine getirir" ve $X=4,59$ aritmetik ortalama ile "Okuldaki faaliyetlerin öğretmenler tarafından desteklenmesini ister ve bunu gerçekleştirebilmek için de çeşitli yollar geliştirir" maddelerinde "her zaman" düzeyinde en fazla etkili oldukları davranışlar olduğunu düşünmektedirler. Buna karşılık öğretmenler $\mathrm{X}=$ 3,98 aritmetik ortalamayla "Okul hakkında çevreye bilgi vermek için çeşitli programlar hazırlar" maddesine "Çoğu zaman" ve X = 4,27 aritmetik ortalama ile “Okul personelinin ihtiyaçlarını ve görevlerini belirlemek için pratik yollar geliştirir" maddesine "her zaman" düzeyinde en az etkili oldukları görüşündedirler. Bununla birlikte öğretmenler 17 madde bulunan "teknik beceriler" boyutunda okul yöneticilerinin X = 4.42 aritmetik ortalama ile "her zaman" düzeyinde etkili oldukları görüşündedirler. Bu duruma göre “teknik becerilerin” mesleğe uzmanlık bilgisi olduğu dikkate alınırsa ilk ve ortaokul yöneticilerini okul yönetiminde uzman olarak gördükleri söylenebilir.

İlk ve ortaokul yöneticilerinin yönetsel etkililikte “insan ilişkileri Becerileri” boyutuna ilişkin öğretmenlerinin görüşleri Tablo 4'te verilmiştir.

Tablo 4: Okul Yöneticilerinin “insan İlişkileri Becerileri” Boyutuna İlişkin Öğretmen Görüşleri

\begin{tabular}{|c|c|c|c|c|}
\hline \multirow{7}{*}{ 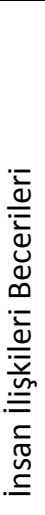 } & Madde & ífade & $\mathbf{x}$ & SS \\
\hline & 2 & $\begin{array}{l}\text { Okuldaki öğretmenlere ve diğer personele içten bir saygı gösterir ve onların } \\
\text { takdirini kazanır. }\end{array}$ & 4,58 & 0,77 \\
\hline & 3 & $\begin{array}{l}\text { Okuldaki, okul çevresindeki, ilçe ve il düzeyindeki eğitim yetkilileriyle kolayca } \\
\text { anlaşabilecek şekilde haberleşir. }\end{array}$ & 4,56 & 0,83 \\
\hline & 4 & $\begin{array}{l}\text { Personelini, öğretmenlik mesleğinde gelişmeleri ve ilerlemeleri için etkin ve } \\
\text { devamlı çalışmaları yönünde teşvik eder. }\end{array}$ & 4,47 & 0,81 \\
\hline & 5 & Eğitim konusunda etkili olan çevredeki söz sahibi kişilerle ilişki kurar. & 4,36 & 0,85 \\
\hline & 11 & $\begin{array}{l}\text { Okuldaki eğitim-öğretim faaliyetlerinin tartışılacağı toplantıya, okuldaki } \\
\text { personelin hepsini çağırır ve herkesin görüşlerini almaya özen gösterir. }\end{array}$ & 4,71 & .509 \\
\hline & 13 & $\begin{array}{l}\text { Okulun mevcut programına ilişkin bilgileri öğretmenlere ve diğer personele } \\
\text { iletir. }\end{array}$ & 4,67 & .588 \\
\hline
\end{tabular}


16 Öğretmenlere, öğrencilerin kişisel kayıt ve bilgilerini almaları ve kullanmaları için yardım eder.

18 Öğrencilerin disiplin problemlerinin çözümüne katkıda bulunur.

$4,47 \quad 0,79$

24 Okuldaki personelin istedikleri zaman kendisine başvurabilmesi için çeşitli kolaylıklar sağlar.

28 Personel ve sistemdeki düzenli değişmelere yardım eder.

$4,62 \quad 0,67$

$4,71 \quad 0,66$

$4,53 \quad 0,65$

30 Okulda çalışan personele görev verirken, bu görevin onların yeteneklerine uygun olmasına dikkat eder.

32 Okulun işleyişi ile ilgili günlük faaliyetleri öğretmenlere en az yük getirecek biçimde yürütür.

38 Okul çevresine bilgi verme programına katılmaları için öğretmenleri ve öğrencileri teşvik eder.

39 Okuldaki öğretmenlerle hem resmi, hem de resmi olmayan ortamlarda iyi ilişkiler kurar.

40 Okuldaki görevlerini yerine getirirken, okulun politikasına uymaya özen gösterir.

45 Sorumluluk taşıyan bir vatandaş olarak, çevredeki derneklere ve faaliyetlere katılır veya söz konusu derneklerin çalışmalarına yardım eder.

51 Okulda çalışan her kişinin okulun başarısına olan katkısını bilir ve layık olanları takdir eder.

$4,49 \quad 0,75$

$4,33 \quad 0,92$

$4,19 \quad .966$

$4,52 \quad 0,80$

$4,63 \quad 0,73$

$4,06 \quad 1,07$

$4,37 \quad 0,94$

55 Okul çevresinin yapısını ve özelliklerini tüm öğretmenlere açık olarak anlatır.

$4,45 \quad 0,94$

56 Öğrenciler arasında arkadaşlık ve dostluğa dayalı bir havanın geliştirilmesine büyük önem verir.

$4,54 \quad 0,79$

Tablo 4 incelendiğinde öğretmenler okul yöneticilerinin $X=4,71$ aritmetik ortalama ile “Okuldaki eğitim-öğretim faaliyetlerinin tartışılacağı toplantıya, okuldaki personelin hepsini çağırır ve herkesin görüşlerini almaya özen gösterir" ve $X=4,67$ aritmetik ortalama ile "Okulun mevcut programına ilişkin bilgileri öğretmenlere ve diğer personele iletir" maddelerinde "her zaman" düzeyinde en fazla etkili oldukları davranışlar olduğunu düşünmektedirler. Buna karşılık öğretmenler $X=4,06$ aritmetik ortalamayla "Sorumluluk taşıyan bir vatandaş olarak, çevredeki derneklere ve faaliyetlere katılır veya söz konusu derneklerin çalışmalarına yardım eder" ve $X=4,19$ aritmetik ortalama "Okul çevresine bilgi verme programına katılmaları için öğretmenleri ve öğrencileri teşvik eder" maddelerinde "Çoğu zaman" düzeyinde" en az etkili oldukları görüşündedirler. Bununla birlikte öğretmenler 19 madde bulunan "insan ilişkileri becerileri" boyutunda okul yöneticilerinin $X=4,48$ aritmetik ortalama ile "her zaman" düzeyinde etkili oldukları görüşündedirler.

İlk ve ortaokul yöneticilerinin yönetsel etkililikte "Kavramsal Beceriler" boyutuna ilişkin öğretmenlerinin görüşleri Tablo 5'te verilmiştir.

Tablo 5. Okul Yöneticilerinin "Kavramsal Beceriler" Boyutuna Illişkin Öğretmen Görüşleri

\begin{tabular}{|c|c|c|c|c|}
\hline \multicolumn{2}{|c|}{ - Madde } & İfade & $x$ & SS \\
\hline $\begin{array}{ll}\overline{0} & \bar{c} \\
& c \\
\varepsilon & \alpha\end{array}$ & 1 & $\begin{array}{l}\text { Okuldaki eğitim-öğretim programının işletilmesini, görevinin tamamı olarak } \\
\text { değil, sadece bir kısmı olarak görür. }\end{array}$ & 2,29 & 1,64 \\
\hline
\end{tabular}


7 Disiplini sadece cezalandırıcı değil eğitici bir önlem olarak görür.

$4,34 \quad 0,89$

10 Okul personeli arasındaki arkadaşlık ilişkilerinin olumlu olması için, iyi bir iş ilişkisinin kurulmasının gerekli olduğunu düşünür.

$4,61 \quad 0,70$

15 Okuldaki bürokrasiyi, en alt düzeyde yapılması gereken işler olarak görür.

17 Okul çevresindeki eğitsel faaliyetlerde, yöneticinin etkili bir rol oynaması gerektiğine inanır.

21 Okulun görevlerini başarılı bir biçimde yerine getirebilmesi için, oku personelinin geliştirilmesinin ve yönlendirilmesinin zorunlu olduğuna inanır.

23 Çevre tarafından "iyi" olarak bilinen okulun, çevrenin desteğini 4,56 0,73 kazanabileceğine inanır.

26 Okuldaki personele bir görev verirken, onların okula ve okulun amaçlarına yaklaşım biçimlerine dikkat eder.

27 Milli eğitimin merkez ve taşra teşkilatının aynı amaç doğrultusunda çalışmaları gerektiğini düşünür.

33 Öğrencilerin okuldaki sosyal faaliyetlere katılmalarını olumlu bulur.

$4,55 \quad 0,75$

$4,44 \quad 0,75$

$4,63 \quad 0,62$

$4,54 \quad 0,70$

34 Öğretmenlerin okulun işleyişine ilişkin görüşlerini söyleyebilmeleri için özendirilmesi ve desteklenmesi gerektiğine inanır.

35 Okulun başarılı olabilmesi için, öğretmenler arasındaki ilişkilerin uyumlu olması gerektiğine inanır.

36 Öğretmeye ayrılan sürede gerçekleştirilen konu dışı faaliyetlerin öğrenmeyi $\quad 3,54 \quad 1,22$ tehlikeye sokacağına inanır.

43 Her kurumu kendi bütünlüğü içinde ele almayı, okul müdürünün en önemli $4,36 \quad 0,83$ fonksiyonlarından biri kabul eder.

44 Okuldaki öğrenci yaşantılarının tümünü müfredat olarak algılar. $\quad 3,79 \quad 1,17$

47 Okuldaki personel arasında iyi bir iş bölümünün gerçekleştirilmesini önemli bir $\quad 4,50 \quad 0,83$ yönetim fonksiyonu olarak görür.

48 Okul ile okul çevresi arasındaki ilişkilerde okulun fonksiyonunu ve önemini 4,66 0,69 vurgular.

49 Okulun amaçlarını gerçekleştirmek için iyi bir haberleşme sisteminin gerekli olduğuna inanır.

50 Müfredatın çevreye uyumunun sağlanması, öğrenciler, okul ve çevre üzerindeki etkisini dikkate alır.

54 Okulun işleyişini geliştirmek ve amaçlarını geçekleştirmek için atılması gereken adımları önceden görür.

$4,66 \quad 0,69$

57 Öğretmeni, toplumun hizmetinde çalışan bir görevli olarak kabul eder.

$4,50 \quad 0,74$

Tablo 5 incelendiğinde öğretmenler okul yöneticilerinin $X=4,66$ aritmetik ortalama ile “Okuldaki öğrenci yaşantılarının tümünü müfredat olarak algılar" ve $X=4,63$ aritmetik ortalama ile "Okuldaki personele bir görev verirken, onların okula ve okulun amaçlarına yaklaşım biçimlerine dikkat eder" maddelerinde "her zaman" düzeyinde en fazla etkili oldukları davranışlar olduğunu düşünmektedirler. Buna karşılık öğretmenler $X=2,29$ aritmetik ortalamayla "Okuldaki eğitim-öğretim programının işletilmesini, görevinin tamamı olarak değil, sadece bir kısmı olarak görür" "Çok seyrek" ve $X=3,79$ aritmetik ortalama "Okuldaki öğrenci yaşantılarının tümünü müfredat olarak algılar" "Çoğu zaman" düzeyinde en az etkili oldukları yönünde görüş belirtmişlerdir. Bununla birlikte öğretmenler 21 madde bulunan "Kavramsal Beceriler" boyutunda okul yöneticilerinin X $=4,31$ aritmetik ortalama ile "her zaman" 
düzeyinde etkili oldukları görüşündedirler. Bununla birlikte öğretmenler 19 madde bulunan "insan ilişkileri becerileri" boyutunda okul yöneticilerinin $X=4,48$ aritmetik ortalama ile "her zaman" düzeyinde etkili oldukları görüşündedirler.

Okul yöneticilerinin yönetiminde etkililik düzeylerine ilişkin öğretmenlerin cinsiyet değişkenine göre görüşleri arasında anlamlı fark olup olmadığı ile ilgili yapılan t-testi Tablo $6^{\prime}$ da verilmiştir.

Tablo 6: Okul Yöneticilerinin Etkililik Düzeylerine ilişsin Cinsiyet Değişkenine Ait Öğretmen Görüşleri

\begin{tabular}{|c|c|c|c|c|c|c|c|c|}
\hline Ölçek & & Cinsiyet & $\mathbf{N}$ & $x$ & Ss & sd & $\mathbf{t}$ & $\mathbf{p}$ \\
\hline Etkililik & & Kadın & 52 & 4,30 & ,67353 & 110 & 2,244 & ,009* \\
\hline Ölçeği & Toplam & Erkek & 60 & 4,52 & ,38114 & & & \\
\hline
\end{tabular}

$* p<.05$

Tablo 6 incelendiğinde ilk ve ortaokul yöneticilerinin etkililik düzeylerine ilişkin ölçek maddelerinin tamamında kadın ve erkek öğretmenlerin görüşleri arasında anlamlı fark vardır $(p<.05)$. Kadın öğretmenler $X=4,30$ aritmetik ortalama ile erkek öğretmenlere $(4,52)$ göre okul yöneticilerinin daha az etkili oldukları yönünde görüş bildirmişlerdir.

Okul yöneticilerinin yönetiminde etkililik düzeylerine ilişkin öğretmenlerin yaş değişkenine göre görüşleri arasında anlamlı fark olup olmadığı ile ilgili yapılan Tek Yönlü Varyans Analiziz sonuçları Tablo 7'de verilmiştir.

Tablo 7: Okul Yöneticilerinin Etkililik Düzeylerine İlişkin Yaş Değişkenine Ait Öğretmen Görüşleri

\begin{tabular}{clccccc} 
Puan & Var. K. & $K T$ & $S d$ & KO & $F$ & $p$ \\
\hline \multirow{4}{*}{ Yaş } & G.Arası & 1,349 & 3 &, 450 & & \\
& G.İçi & 31,810 & 108 &, 295 & 1,526 &, 212 \\
& Toplam & 33,159 & 111 & & & \\
\hline \multicolumn{6}{c}{$*$} & $p>0,05$
\end{tabular}

Tablo 7 incelendiğinde, öğretmenlerin okul yöneticilerinin yönetiminde etkililik düzeylerine ilişkin görüşlerinde yaş değişkenine göre anlamlı bir farklılık gösterip göstermediğini belirlemek amacıyla yapılan tek yönlü varyans analizi (ANOVA) sonucunda, grupların aritmetik ortalamaları arasındaki farklılık istatistiksel olarak anlamlı bulunmamıştır $(F=1,526 ; p>0,05)$. Bu bulgulara göre öğretmenlerinin okul yöneticilerinin etkililik düzeylerine ilişkin yaş değişkeni açısından görüşleri birbirine benzerdir.

Okul yöneticilerinin yönetiminde etkililik düzeylerine ilişkin öğretmenlerin hizmet yılı değişkenine göre görüşleri arasında anlamlı fark olup olmadığı ile ilgili yapılan Tek Yönlü Varyans Analiziz sonuçları Tablo 8' de verilmiştir. 
Tablo 8: Okul Yöneticilerinin Etkililik Düzeylerine İlişkin Hizmet Yılına Ait Öğretmen Görüşleri

\begin{tabular}{|c|c|c|c|c|c|c|}
\hline Puan & Var. K. & $K T$ & $S d$ & $\mathrm{KO}$ & $F$ & $p$ \\
\hline \multirow{3}{*}{ Kıdem } & G.Arası & 1,868 & 4 & 467 & & \\
\hline & G.íçi & 31,291 & 107 & 292 & 1,597 & 180 \\
\hline & Toplam & 33,159 & 111 & & & \\
\hline
\end{tabular}

Tablo 8'e göre, öğretmenlerin okul yöneticilerinin yönetsel etkililik düzeylerine ilişkin görüşlerinde kıdem değişkenine göre anlamlı bir farklılık gösterip göstermediğini belirlemek amacıyla yapılan tek yönlü varyans analizi (ANOVA) sonucunda, grupların aritmetik ortalamaları arasındaki farklılık istatistiksel olarak anlamlı bulunmamıştır $(F=1,526 ; p>0,05)$. Bu bulguya göre öğretmenlerinin okul yöneticilerinin yönetsel etkililik düzeylerine ilişkin kıdem değişkeni açısından görüşleri birbirine benzerdir.

\section{SONUÇLAR VE TARTIŞMA}

Öğretmenler okul yöneticilerinin 17 madde bulunan "teknik beceriler" boyutunda $X=$ 4.42 aritmetik ortalama ile "her zaman", 19 madde bulunan "Insan illişkileri Becerileri" boyutunda $X=4,48$ aritmetik ortalama ile "her zaman" ve 21 madde bulunan "Kavramsal Beceriler" boyutunda $X=4,31$ aritmetik ortalama ile yine "her zaman" düzeyinde etkili oldukları görüşündedirler. Ayrıca öğretmenler okul yöneticilerini ölçme aracının tamamında 4,40 aritmetik ortalama ile "her zaman" düzeyinde etkili bulmaktadırlar. Bu duruma göre öğretmenler okul yöneticilerini en fazla insan ilişkilerinde etkili bulurken en az teknik beceriler konusunda etkili bulmaktadırlar.

Erkek öğretmenler kadın öğretmenlere oranla okul yöneticilerini yönetsel bakımdan daha etkili bulmaktadırlar. Bu durumda kadın öğretmenler ile erkek öğretmenlerin yönetsel etkililik konusunda farklı algılara sahip oldukları sonucuna varılabilir. Öğretmenlerin hizmet yılı ve yaş değişkenine göre okul yöneticilerinin yönetsel etkililikleri konusunda görüşlerinde anlamlı fark yoktur. Bir başka deyişle hizmet yılı ve yaş değişkeni okul yöneticilerinin yönetsel etkililiklerini algılamada fark ortaya koymamaktadır.

Alanyazında okul yöneticilerini etkililik ve yeterliklerine ilişkin farklı bakış açılarını içeren çeşitli araştırmalar yapılmıştır. Harrison (2008) tarafından okul yöneticilerinin etkililik düzeylerini belirlemek amacıyla yapılan araştırmada da benzer şekilde öğretmenler okul yöneticilerini okul yönetiminde etkili olarak değerlendirmektedirler. Koçak ve Helvacı (2011) tarafından okul yöneticilerinin etkililik düzeylerini belirlemek amacıyla Uşak ilinde yapılan araştırmada ilk ve ortaokullarda görev yapan okul yöneticilerinin veri toplama aracının tüm boyutlarında "çok" düzeyinde etkili oldukları ve öğretmen görüşlerinin cinsiyet ve kıdem 
değişkenlerine göre aralarında anlamlı bir farklılık olmadığı $\mathrm{S}$ onucuna ulaşılmıştır. Karakuş ve Töremen (2006) tarafından yapılan ve denetçi gözüyle yönetici yeterliklerinin belirlenmesi amacıyla Elazığ, Malatya, Adıyaman ve Bingöl illerinin kapsayan araştırma sonucunda ise ilk ve ortaokul yöneticilerinin genel olarak yöneticilik özelliklerini yansıttıkları, bunun yanında modem liderlik davranışlarının birçoğunu yansıtmadıkları belirlenmiştir. Gökçe (2004), Argon ve Özçelik (2007), Yıldız (2012) tarafından yapılan ve okul yöneticilerinin değişimi yönetme yeterliklerini ortaya koymak amacıyla yapılan araştırmada ise okul yöneticilerinin "iyi" "çok" düzeyinde değişimi yönetme yeterliğine sahip oldukları sonucuna varılmıştır.

\section{KAYNAKLAR}

Açıkalın, A. (2006). “Okul müdürü de insandır. Okul Yönetimlerini Geliştirme Programı. (ss. 153159) İçinde. Ankara: İlköğretim Genel Müdürlüğü.

Açıkalın, A. ve Çınkır, Ş. (2006). Farklı yönetici yeterlilikleri. Okul Yönetimlerini Geliştirme Programı. (s. 119-127) İçinde. Ankara: İlköğretim Genel Müdürlüğü.

Argon, T. ve Eren, A. (2004).Insan Kaynakları Yönetimi. Ankara: Nobel Yayınları.

Argon, T. Özçelik, N. (2007). Illköğretim Okulu Yöneticilerinin Değişimi Yönetme Yeterlikleri. Mehmet Akif Ersoy Üniversitesi Eğitim Fakültesi Dergisi. 8 (16), s.70-89.

Aydın, M. (1994). Çağdaş Eğitim Denetimi. Ankara: PEGEM Yayın No: 4.

Aydın, M. (1991). Eğitim Yönetimi. Ankara: Hatiboğlu Yayınevi.

Balcı, A. (2001). Etkili Okul Ve Okul Geliştirme. Ankara: Pegem Yayıncılık.

Balcı, A. (1993). Etkili Okul, Ankara: Erek Ofset.

Balcı, A. (2006). Türk Eğitim Sisteminde Yeni Paradigma Arayışları. Ankara: Eğitim-Bir Sen Bildiriler Kitabı.

Balcı, A. (1988). Etkili Okul. Ankara: Eğitim ve Bilim. Sayı:17.S.12 Ekim.

Bayrak, Ç. (2001). Bir sistem olarak okul. Ö. Demirel-Z. Kaya (Ed.), Öğretmenlik Mesleğine Giriş. Ankara, Pegem Yayıncılık.

Can, H. (1994). Organizasyon ve Yönetim. Ankara: Siyasal Kitapevi.

Can, H. (2002). “Değişim Sürecinde Eğitim Yönetimi”. Eğitim Yönetimi Dergisi. Sayı 155-156.

Can, N. (2004). Sınıfta bir lider olarak öğretmen. M. Şişman, S. Turan (Ed.), Sınıf Yönetimi. (ss. 130-139) İçinde. Ankara, Pegem A Yayıncılık.

Dönmez, B. (1999). Değişme ve Yenileşme. E. Toprakçı (Ed.), Yönetici Adayları Eğitim Programı. (13-29) İçinde. Malatya: İnönü Üniversitesi Yayını.

Drucker, P. F.(1992). Etkin Yöneticilik. (Çev. Ahmet Özdan, Nuray Tunalı) İstanbul: Eti Kitapları Yön. Matbaacılık. 
Gökçe, F. (2004). Okulda Değişmenin Yönetimi. Uludağ Üniversitesi Eğitim Fakültesi Dergisi. XVII (2), 2004,

Harrison, B.L(2008). The Perceptions Of Teachers And School Administrators Of School Effectıveness In 11 Schools In A Southern MIssissippı School District. Mississippi State, Mississippi. USA.

Ilgar, L. (2005). Eğitim Yönetimi, Okul Yönetimi, Sınıf Yönetimi. İstanbul: Beta Basım Yayım Dağııım A.Ş.

Karakuş, M. Töremen F. (2006). Denetçi gözüyle Yönetici yeterlikleri: ilköğretim okulu Yöneticileri üzerine Bir Araştırma. Kazım Karabekir E2itim Fakültesi Dergisi Yıl:2006 Sayı:13

Karip, E. vd. (2005). Eğitim ve Okul Yöneticiliği El Kitabı. Ankara: Pegem Yayıncılık.

Karasar, N. (2011). Bilimsel Araştırma Yöntemi -Kavramlar, ilkeler, Teknikler-. 22. Baskı Ankara: Nobel Yayınevi.

Karslı, D.K. (1998).Yönetsel Etkililik. Bolu: AïÜ. Yayınları No 6.

Koçak, F. Helvacı, M.A. (2011). "Okul Yöneticilerinin Etkililiği (Uşak ili Örneği)” Eğitim Bilimleri Araştırmaları Dergisi, Cilt 1, Sayı 1, Haziran 2011.

Koçel, T. (2003). İşletme Yöneticiliği. İstanbul: Beta Basım Yayım Dağıtım.

Korkmaz, A. (1997). Toplam Kalite Yönetiminin Eğitime Etkisi ve Ilkeleri. Milli Eğitim. Sayı:135. S.47.

Şişman, M. ve Turan, S. (2005). Eğitim ve Okul Yöneticiliği El Kitabı. Ankara: Pegem Yayıncılık.

Şişman, M. (2005). Eğitim Ve Okul Yöneticiliği El Kitabı Ankara: Pegem Yayıncılık,

Şişman, M. (2001). Eğitimde Mükemmellik Arayışı: Etkili Okullar. Ankara: Pegem Yayınları.

Şişman, M. (1996). Etkili Okul Yönetimi. Eskişehir: Anadolu Üniversitesi Yayınlar.

Tekin, H. (1996). Eğitimde Ölçme ve Değerlendirme, Ankara: Yargı Yayınları.

Tanrıöğen, A. (1988).Okul Müdürlerinin Etkililiği Ile Öğretmen Morali Arasındaki ～ilişkiler. Yayınlanmamış Doktora Tezi, Hacettepe Üniversitesi, $\quad$ Ankara.

Tengilimoğlu, D., Atilla, E. A. ve Bektaş, M. (2008). İşletme Yönetimi. Ankara: Seçkin Yayıncılık.

Yıldız, K. (2012). Yöneticilerin Değişimi Yönetme Yeterlikleri. Aї̈̈̈ Sosyal Bilimler Enstitüsü Dergisi, Güz 2012, Cilt:12, Yıl:12, Sayı:2, 12: 177-198 